\title{
Responses of aeolian desertification to a range of climate scenarios in China
}

\author{
Xunming Wang ${ }^{1}$, Ting Hua ${ }^{1,2}$, and Wenyong Ma ${ }^{1}$ \\ ${ }^{1}$ Key Laboratory of Water Cycle and Related Land Surface Processes, Institute of Geographic Sciences and Natural \\ Resources Research, Chinese Academy of Sciences, Beijing 100101, China \\ ${ }^{2}$ Key Laboratory of Desert and Desertification, Cold and Arid Regions Environmental and Engineering Research Institute, \\ Chinese Academy of Sciences, Lanzhou 730000, China \\ Correspondence to: Xunming Wang (xunming@igsnrr.ac.cn)
}

Received: 29 March 2016 - Published in Solid Earth Discuss.: 13 April 2016

Revised: 31 May 2016 - Accepted: 31 May 2016 - Published: 16 June 2016

\begin{abstract}
Aeolian desertification plays an important role in earth-system processes and ecosystems, and has the potential to greatly impact global food production. The occurrence of aeolian desertification has traditionally been attributed to increases in wind speed and temperature and decreases in rainfall. In this study, by integrating the aeolian desertification monitoring data and climate and vegetation indices, we found that although aeolian desertification is influenced by complex climate patterns and human activities, increases in rainfall and temperature and decreases in wind speed may not be the key factors of aeolian desertification controls in some regions of China. Our results show that, even when modern technical approaches are used, different approaches to desertification need to be applied to account for regional differences. These results have important implications for future policy decisions on how best to combat desertification.
\end{abstract}

\section{Introduction}

Desertification is a process that affects the sustainability of global ecosystems (Barbero-Sierra et al., 2015; Escadafal et al., 2015; Miao et al., 2015; Torres et al., 2015), of the soils and the hydrological, biological, and geochemical processes, and of human societies (e.g. Brevik et al., 2015; Mekonnen et al., 2015; Smith et al., 2015; Keesstra et al., 2016). In China, aeolian desertification mainly occurs when arable land and grassland are degraded to such a degree that aeolian transport is exacerbated by decreases in vegetation cover or increases in the intensity of aeolian processes (Wang et al., 2005;
Houyou et al., 2014; Martínez-Graña et al., 2015), and when anchored or semi-anchored dunes are reactivated (Zhang et al., 2014; Wang et al., 2015). In the last 50 years, there have been several periods with high or low rates of dune reactivation and degradation of arable land and grassland, with corresponding occurrences of desertification and rehabilitation. Aeolian desertification may give rise to land surfaces that can no longer support cultivation or husbandry (UNEP, 1992; UNCED, 1992), and cause decreases in biomass and species richness, loss of herbaceous species, and reductions in crop and meat production (Schlesinger et al., 1990; Reynolds et al., 2001; Wang et al., 2008; Okin et al., 2009; Colazo et al., 2015; Borrelli et al., 2016). Land that is at risk from aeolian desertification in China is mainly located on the boundaries of Sandy and Gobi deserts. The affected area stretches from central Asia in the west to northeastern China in the east, and covers more than 1.83 million $\mathrm{km}^{2}$ (DCSNBSC, 2005; State of Forestry Administration of China, 2011) and occupies almost $70 \%$ of the total area at risk from desertification. This land is currently managed as traditional pastoral and agricultural systems, but if aeolian desertification continues to expand, the livelihoods of nearly 400 million people will be jeopardized (DPSSTS, 2002). By the mid-2000s, costs associated with the loss of loess attributable to aeolian desertification exceeded RMB 50 billion (approximately USD 8 billion) (The Central People's Government of the People's Republic of China, 2005).

Increases in wind speed and decreases in rainfall have traditionally been considered to trigger aeolian desertification (Okin and Gillette, 2001; Field et al., 2009; Sankey et al., 
2012; Xu and Zhang, 2014; Xie et al., 2015). Aeolian processes may also have different consequences on ecosystems (Vieira et al., 2015), as windblown dust inputs can contribute to soil formation and provide essential nutrients (Reynolds et al., 2007), indirectly cause reductions in perennial vegetation cover of plant communities in the receiving area (Cerd and Lavee, 1999; Munson et al., 2011; Bisaro et al., 2014), promote land rehabilitation, and introduce plants to areas far from their natural habitat. In addition, although there is uncertainty regarding the contribution of variations in temperature to global terrestrial net primary production (Balling Jr., 1991; Nemani et al., 2003), the temperature rise may benefit the rehabilitation in some regions of China (Wang et al., 2009), while in some regions it may trigger aeolian desertification (Xue et al., 2009).

Given the huge potential risks to ecological security, pastoral and agricultural systems, and crop and meat production posed by aeolian desertification, national and district level governments in China implemented numerous programs between the 1970s and early 2010s (Zhu, 1994; Ministry of Science and Technology of the People's Republic of China, 2005) to extensively monitor, mitigate, and control aeolian desertification throughout China. However, before these control programs were carried out, the impacts of climate variations on aeolian desertification has not been appraised (Wang et al., 2006, 2010). Without robust testing, the most common mitigation measures applied throughout China have been afforestation, conversion of tilled land to forestry and grassland, and prevention of grazing (The State Council of the People's Republic of China, 2002, 2007).

Even with modern technological tools, the principle methods used to mitigate aeolian desertification in China still rely on improved soil moisture conditions and decreases in wind speed (The Central People's Government of the People's Republic of China, 2013). However, regional differences mean that, in some regions, the process of desertification is highly sensitive to variations in rainfall, whereas in other regions it is highly sensitive to variations in wind speed and temperature (Wang et al., 2008). In this study, we integrated variations in trends in temperature, wind speed, and rainfall, and determined their relationships with aeolian desertification in China, and provided information for future policy decisions on how best to combat desertification.

\section{Materials and methods}

There were great spatial differences in the aeolian desertification and the landscape characteristics in different regions of China (Fig. S1 in the Supplement). For instance, in northeastern China, aeolian desertification is mainly exhibited by anchored or semi-anchored dunes/sand sheets being reworked into mobile or semi-anchored dunes/sand sheets, while in central China, the main aeolian desertification form is the degradation of arable land and grassland (Wang et al.,
2008). Therefore, according to the spatial differences of landscape characteristics, the aeolian desertification monitoring programs were carried out at the local levels.

There have been five aeolian desertification monitoring campaigns over the past 40 years. Based on these monitoring results, and using the monitoring criteria listed in Supplement Table S1, aeolian desertification has been categorized into four types of aeolian desertification, namely: slight, moderate, severe, and very severe. Subsequently, the entire area of China at risk from aeolian desertification was divided into 29 areas (four overlapping regions were excluded from the main part of this contribution and the results have been shown in Fig. S3) using the monitoring criteria (Fig. S2). Monitoring was carried out in 1975, 1990, 2000, 2005, and 2010, and detailed results have been reported by Wang (2014). In addition, although previous studies (e.g. Algayer et al., 2014) suggested that some non-erodible areas such as those with crusted soil or rocky surfaces may have low aeolian desertification risks, the areas are very small (e.g. Wang, 2014) and had nearly no effects on the analysed results.

Temperature, rainfall, and wind speed data from 750 meteorological stations around China were acquired from the Chinese Meteorological Administration. Mean annual data were spatially interpolated using the inverse distance weighting method (Tang et al., 2011). In addition, monthly values of the Palmer Drought Severity Index (PDSI) with a temporal resolution of $2.5^{\circ} \times 2.5^{\circ}$ were used to evaluate variations in atmospheric moisture supply and demand (Palmer, 1965). This index incorporated the antecedent and current moisture supply and demand into a hydrological model that includes a two-layer bucket-type model for soil moisture calculations (Dai et al., 2004).

In order to estimate the relationship between aeolian desertification and climate factors, Spearman correlation coefficients were calculated between areas of aeolian desertification and the climate indices in the monitoring regions. Before the Spearman correlations were performed, all climate indices were divided into periods that corresponded with the monitoring intervals for aeolian desertification (Table S2).

\section{Results and discussion}

Our results show that, for most regions with high risks of aeolian desertification, variations in rainfall and the occurrence of aeolian desertification are not closely related (Fig. 1a), and increases in rainfall have only resulted in the rehabilitation that has taken place in areas such as the Tarim Basin, the source area of the Yellow River, the Qinghai Lake Basin, and the Heihe and Kachgar drainage areas. In contrast, in areas such as the Junggar Basin, the Turpan-Kumul Basin, the Kachgar drainage basin, and the northeastern autonomous region of Ningxia, increases in rainfall still gave rise to slight to moderate aeolian desertification. The possible reasons for 

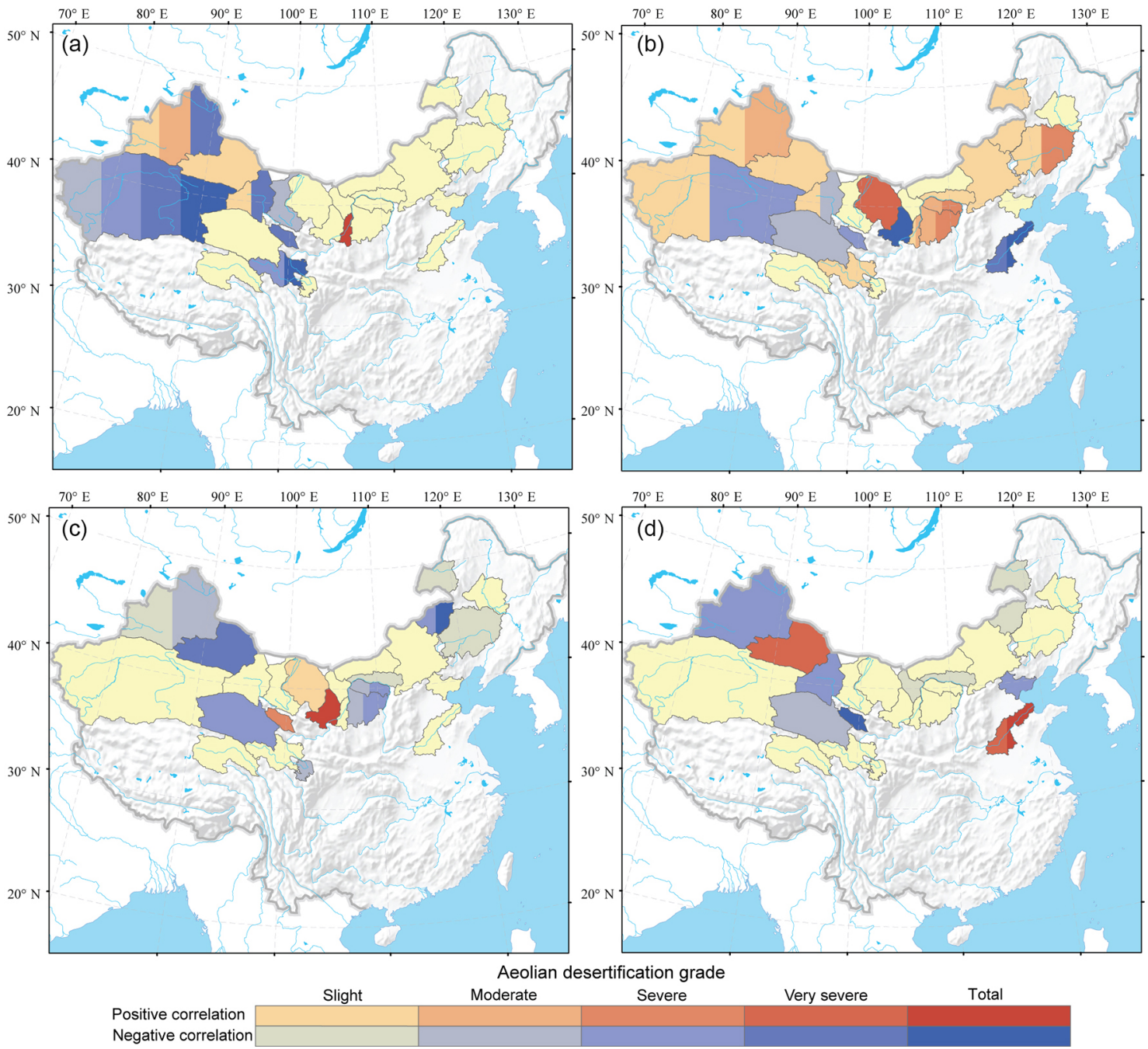

Figure 1. Spearman correlations between variations in areas of aeolian desertification and (a) rainfall, (b) temperature, (c) wind speed, and (d) the Palmer Drought Severity Index (PDSI). Main areas where aeolian desertification monitoring takes place are shown in Fig. S2. Regions where negative/positive correlations are significant at the 0.05 level (two-tailed) are shown in blue/red, and regions where correlations were not significant at the 0.05 level (two-tailed) are shown in yellow. Detailed correlation results are provided in Table S3.

this may be that the impacts of human activities on aeolian desertification have exceeded the impacts of rainfall variations in such regions (Gao et al., 2016).

As with the response of aeolian desertification to variations in rainfall, the responses of aeolian desertification to various degrees of temperature increase were variable (Fig. 1b). In China, increases in temperature are beneficial for rehabilitation in areas where there is a high risk of aeolian desertification, such as the Tarim Basin, the Kachgar drainage area, the Qaidam Basin, Qinghai Lake Basin, the Tangier Desert, and the lower reaches of the Yellow River that have been classified with different desertification grades. In these regions, although increases in temperature may lead to higher evaporation and higher aridity, and consequently, trigger aeolian desertification, the increases in temperature may also benefit the vegetation growth (Piao et al., 2006) and result in rehabilitation occurrence. Further, our results show that, for most regions, there are no close relationships between variations in wind speed and aeolian desertification (Fig. 1c), and increases in wind speed resulted in aeolian desertification only in areas such as the Qinghai Lake Basin, and the Badain Jaran and Tengger deserts, suggesting that aeolian transport is one of the key factors of desertification in these regions. In particular, our statistical results show that increases in wind speed may promote rehabilitation in areas with changeable aeolian desertification grades, such as the Junggar Basin, the Turpan-Kumul Basin, the Qaidam Basin, the Zoige Plateau, the Mu Us Desert, and the Xilin Gol Grasslands. These results suggested that in these regions, although the increases in wind speed may trigger aeolian desertification, temperature and rainfall variations may result in rehabilitation occurrence. 
Similar to the relationships between aeolian desertification and variations in rainfall, temperature, and wind speed, there are also spatial variations in the responses of aeolian desertification to surface soil moisture conditions (Fig. 1d). For example, correlation analysis between the Palmer Drought Severity Index (PDSI) and areas impacted by aeolian desertification shows that increases in soil moisture may result in rehabilitation in the Junggar Basin, the Kachgar drainage area, the Qaidam Basin, the Luanhe-Yongding drainage area, and Qinghai Lake basin regions, but may trigger slight aeolian desertification in the Turpan-Kumul Basin and the lower reaches of the Yellow River, which is not consistent with the conventional perception that increases in the PDSI may improve rehabilitation of the region (Jeong et al., 2011; Peters et al., 2012). In addition, our results show that just as there is variation between the monitoring areas, the correlations between the areas impacted by aeolian desertification and climate indices are also variable. Within limited areas, the degree of aeolian desertification is highly sensitive to the intensity of the aeolian processes (Wang et al., 2008), which results in variable relationships between the responses of aeolian desertification and climate indices. These results also suggest that regionalization is a vital issue for desertification mitigation programs. Furthermore, although the impacts of climate change on land degradation are only visible after a relatively long period (Herrmann et al., 2005; VicenteSerrano et al., 2013), monitoring results that extend beyond periods of 5 years indicate that, in addition to the lagged responses of aeolian desertification to various climate indices, increases in rainfall and temperature and decreases in wind speed may also trigger aeolian desertification on the regional scale, and may therefore introduce uncertainty into assessments of the impacts of climate change on landscape evolution.

In the last 50 years, human activities such as reclamation and increased grazing intensity in China may have accelerated the process of aeolian desertification (Wang et al., 2006; Gao et al., 2016); however, other human activities that can be beneficial to rehabilitation, such as afforestation, conversion of tilled land to forestry and grassland, and prevention of grazing, have also been put into practice (Cao et al., 2011). To some degree, the inconsistency of these practices has also contributed to the confusing response of aeolian desertification to various climate indices.

\section{Conclusions}

Although increases in rainfall and surface soil moisture conditions and decreases in wind speed may promote rehabilitation over longer timescales and across larger spatial scales, they also may trigger aeolian desertification in some areas. Monitoring of aeolian desertification in China over recent decades shows that desertification has responded in various ways to climate indices. Even when modern technical ap- proaches are applied, the complex patterns of climate and human activities and the variability between regions mean that a range of desertification control practices should be applied, and the measures to combat desertification have to be set up at the local level. This information has important implications for future policy decisions on how best to combat desertification.

\section{The Supplement related to this article is available online at doi:10.5194/se-7-959-2016-supplement.}

Acknowledgements. This work was supported by the National Science Foundation for Distinguished Young Scholars of China (no. 41225001) and the National Key Project for Basic Research, "Responses of Aeolian Desertification to Global Change in the Qinghai-Tibet Plateau" (2013CB956003). Special thanks are given to the anonymous referees for their critical comments.

Edited by: A. Cerdà

\section{References}

Algayer, B., Wang, B., Bourennane, H., Zheng, F., Duval, O., Li, G., Le Bissonnais, Y., and Darboux, F.: Aggregate stability of a crusted soil: differences between crust and sub-crust material, and consequences for interrill erodibility assessment, An example from the Loess Plateau of China, Eur. J. Soil Sci., 65, 325335, 2014.

Balling Jr., R. C.: Impact of desertification on regional and global warming, B. Am. Meteorol. Soc., 72, 232-234, 1991.

Barbero-Sierra, C., Marques, M. J., Ruiz-Pérez, M., Escadafal, R., and Exbrayat, W.: How is desertification research addressed in Spain? Land versus soil approaches, Land Degrad. Dev., 26, 423-432, 2015.

Bisaro, A., Kirk, M., Zdruli, P., and Zimmermann, W.: Global drivers setting desertification research priorities: Insights from a stakeholder consultation forum, Land Degrad. Dev., 25, 5-16, 2014.

Borrelli, P., Panagos, P., Ballabio, C., Lugato, E., Weynants, M., and Montanarella, L.: Towards a Pan-European assessment of land susceptibility to wind erosion, Land Degrad. Dev., 27, 10931105, 2016.

Brevik, E. C., Cerdà, A., Mataix-Solera, J., Pereg, L., Quinton, J. N., Six, J., and Van Oost, K.: The interdisciplinary nature of SOIL, SOIL, 1, 117-129, doi:10.5194/soil-1-117-2015, 2015.

Cao, S., Chen, L., Shankman, D., Wang, C., Wang, X., and Zhang, H.: Excessive reliance on afforestation in China's arid and semiarid regions, Lessons in ecological restoration, Earth-Sci. Rev., 104, 240-245, 2011.

Cerd, A. and Lavee, H.: The effect of grazing on soil and water losses under arid and mediterranean climates. Implications for desertification, Pirineos, 153/154, 159-174, 1999.

Colazo, J. C. and Buschiazzo, D.: The impact of agriculture on soil texture due to wind erosion, Land Degrad. Dev., 26, 62-70, 2015. 
Dai, A., Trenberth, K. E., and Qian, T.: A global dataset of Palmer Drought Severity Index for 1870-2002, Relationship with soil moisture and effects of surface warming, J. Hydrometeorol., 5, 1117-1130, 2004.

Department of Comprehensive Statistics of the National Bureau of Statistics of China (DCSNBSC): China Compendium of Statistics 1949-2004, China Statistics Press, Beijing, 2005.

Department of Population, Social, Science and Technology Statistics: National Bureau of Statistics of China (DPSSTS) China Population Statistics Yearbook 2002, China Statistics Press, Beijing, 2002

Escadafal, R., Barbero-Sierra, C., Exbrayat, W., Marques, M. J., Akhtar-Schuster, M., El Haddadi, A., and Ruiz, M.: First appraisal of the current structure of research on land and soil degradation as evidenced by bibliometric analysis of publications on desertification, Land Degrad. Dev., 26, 413-422, 2015.

Field, J. P., Breshears, D. D., and Whicker, J. J.: Toward a more holistic perspective of soil erosion, why aeolian research needs to explicitly consider fluvial processes and interactions, Aeolian Res., 1, 9-17, 2009.

Gao, Y., Dang, X., Yu, Y., Li, Y., Liu, Y., and Wang, J.: Effects of tillage methods on soil carbon and wind erosion, Land Degrad. Dev., 27, 583-591, 2016.

Herrmann, S. M., Anyamba, A., and Tucker, C. J.: Recent trends in vegetation dynamics in the African Sahel and their relationship to climate, Global Environ. Chang., 15, 394-404, 2005.

Houyou, Z., Bielders, C. L., Benhorma, H. A., Dellal, A., and Boutemdjet, A.: Evidence of strong land degradation by wind erosion as a result of rainfed cropping in the algerian steppe: A case study at laghouat, Land Degrad. Dev., doi:10.1002/ldr.2295, 2014.

Jeong, S. J., Ho, C. H., Brown, M. E., Kug, J. S., and Piao, S.: Browning in desert boundaries in Asia in recent decades, J. Geophys. Res., 116, D02103, doi:10.1029/2010JD014633, 2011

Keesstra, S. D., Bouma, J., Wallinga, J., Tittonell, P., Smith, P., Cerdà, A., Montanarella, L., Quinton, J. N., Pachepsky, Y., van der Putten, W. H., Bardgett, R. D., Moolenaar, S., Mol, G., Jansen, B., and Fresco, L. O.: The significance of soils and soil science towards realization of the United Nations Sustainable Development Goals, SOIL, 2, 111-128, doi:10.5194/soil-2-1112016, 2016.

Martínez-Graña, A. M., Goy, J. L., and Zazo, C.: Cartographic Procedure for the Analysis of Aeolian Erosion Hazard in Natural Parks (Central System, Spain), Land Degrad. Dev., 26, 110-117, 2015.

Mekonnen, M., Keesstra, S. D., Stroosnijder, L., Baartman, J. E. M., and Maroulis, J.: Soil conservation through sediment trapping: A review, Land Degrad. Dev. 26, 544-556, 2015.

Miao, L., Moore, J. C., Zeng, F., Lei, J., Ding, J., He, B., and Cui, X.: Footprint of Research in Desertification Management in China, Land Degrad. Dev., 26, 450-457, 2015.

Ministry of Science and Technology of the People's Republic of China: available at: www.most.gov.cn/kjbgz/200511/ t20051115_26114.htm, last access: 15 November 2005.

Munson, S. M., Belnap, J., and Okin, G. S.: Responses of wind erosion to climate-induced vegetation changes on the Colorado Plateau, P. Natl. Acad. Sci. USA, 108, 3854-3859, 2011.

Nemani, R. R., Keeling, C. D., Hshimoto, H., Jolly, W. M., Piper, S. C., Tucker, C. J., Myneni, R. B., and Running, S. W.: Climate- driven increases in global terrestrial net primary production from 1982 to 1999, Science, 300, 1560-1563, 2003.

Okin, G. S. and Gillette, D. A.: Distribution of vegetation in winddominated landscapes, implications for wind erosion modeling and landscape processes, J. Geophys. Res., 106, 9673-9683, 2001.

Okin, G. S., Parsons, A. J., Wainwright, J., Herrick, J. E., Bestelmeyer, B. T., Peters, D. C., and Fredrickson, E.: Do Changes in Connectivity Explain Desertification?, BioScience, 59, 237-244, 2009.

Palmer, W. C.: Meteorological drought, US Dept. of Commerce, 1965.

Peters, D. P. C., Yao, J., Sala, O., and Anderson, J. P.: Directional climate change and potential reversal of desertification in arid and semiarid ecosystems, Glob. Change Biol., 18, 151-163, 2012.

Piao, S., Mohammat, A, Fang, J., Cai, Q., and Feng, J.: NDVI-based increase in growth of temperate grasslands and its responses to climate changes in China, Global Environ. Chang., 16, 340-348, 2006.

Reynolds, J. F., Smith, D. M. S., Lambin, E. F., Turner II, B. L., Mortimore, M., Batterbury, S. P. J., Downing, T. E., Dowlatabadi, H., Fernandez, R. J., Herrick, J. E., Huber-Sannwald, E., Jiang, H., Leemans, R., Lynam, T., Maestre, F. T., Ayarza, M., and Walker, B.: Global desertification, Building a science for dryland development, Science, 316, 847-851, 2007.

Reynolds, R., Belnap, J., Reheis, M., Lamothe, P., and Luiszer, F.: Aeolian dust in Colorado Plateau soils, Nutrient inputs and recent change in source, P. Natl. Acad. Sci. USA, 98, 7123-7127, 2001.

Sankey, J. B., Germino, M. J., Benner, S. G., Glenn, N. F., and Hoover, A. N.: Transport of biologically important nutrients by wind in an eroding cold desert, Aeolian Res., 7, 17-27, 2012.

Schlesinger, W. H., Reynolds, J. F., Cunningham, G. L., Huenneke, L. F., Jarrell, W. M., Virginia, R. A., and Whitford, W. G..: Biological feedbacks in global desertification, Science, 247, 1043 1048, 1990.

Smith, P., Cotrufo, M. F., Rumpel, C., Paustian, K., Kuikman, P. J., Elliott, J. A., McDowell, R., Griffiths, R. I., Asakawa, S., Bustamante, M., House, J. I., Sobocká, J., Harper, R., Pan, G., West, P. C., Gerber, J. S., Clark, J. M., Adhya, T., Scholes, R. J., and Scholes, M. C.: Biogeochemical cycles and biodiversity as key drivers of ecosystem services provided by soils, SOIL, 1, 665685, doi:10.5194/soil-1-665-2015, 2015

State Forestry Administration of China: A bulletin of status quo of desertification and sandification in China, available at: www.gov.cn/gongbao/content/2005/content_91640.htm (last access: 25 September 2005), 2011.

Tang, B., Tong, L., Kang, S., and Zhang, L.: Impacts of climate variability on reference evapotranspiration over 58 years in the Haihe river basin of north China, Agr. Water Manage., 98, 16601670, 2011.

The Central People's Government of the People's Republic of China: available at: www.gov.cn/gongbao/content/2005/content_ 91640.htm, last access: 8 September 2005.

The Central People's Government of the People's Republic of China: available at: www.gov.cn/gzdt/2013-03/21/content 2359269.htm, last access: 21 March 2013. 
The State Council of the People's Republic of China: available at: www.gov.cn/gongbao/content/2002/content_61463.htm, last access: 11 April 2002.

The State Council of the People's Republic of China: available at: www.gov.cn/zwgk/2007-08/14/content_716617.htm, last access: 9 August 2007.

Torres, L., Abraham, E. M., Rubio, C., Barbero-Sierra, C., and Ruiz-Pérez M.: Desertification research in Argentina. Land Degrad. Dev., 26, 433-440, 2015.

United Nations Environment Programme (UNEP): World atlas of desertification, edited by: Middleton, N. and Thomas, D., London, 1992.

United Nations Results of the World Conference on Environment and Development, Agenda 21 (UNCED): United Nations Conference on Environment and Development, Rio de Janeiro, United Nations, New York, 1992.

Vicente-Serrano, S. M., Gouveia, C., Camarero, J. J., Begueria, S., Trigo, R., Lopez-Moreno, J. I., Azorin-Molina, C., Pasho, E., Lorenzo-Lacruz, J., Revuelto, J., Moran-Tejeda, E., and SanchezLorenzo, A.: Response of vegetation to drought time-scales across global land biomes, P. Natl. Acad. Sci. USA, 110, 52-57, 2013.

Vieira, R. M. S. P., Tomasella, J., Alvalá, R. C. S., Sestini, M. F., Affonso, A. G., Rodriguez, D. A., Barbosa, A. A., Cunha, A. P. M. A., Valles, G. F., Crepani, E., de Oliveira, S. B. P., de Souza, M. S. B., Calil, P. M., de Carvalho, M. A., Valeriano, D. M., Campello, F. C. B., and Santana, M. O.: Identifying areas susceptible to desertification in the Brazilian northeast, Solid Earth, 6, 347-360, doi:10.5194/se-6-347-2015, 2015.

Wang, T.: Atlas of sandy desert and aeolian desertification in Northern China, Science Press, Beijing, 2014.

Wang, T., Xue, X., Zhou, L., and Guo J.: Combating Aeolian Desertification in Northern China, Land Degrad. Dev., 26, 118-132, 2015 .
Wang, X., Chen, F., Dong, Z., and Xia, D.: Evolution of the southern Mu Us Desert in North China over the past 50 years, an analysis using proxies of human activity and climate parameters, Land Degrad. Dev., 16, 351-366, 2005.

Wang, X., Chen, F., and Dong, Z.: The relative role of climatic and human factors in desertification in semi-arid China, Global Environ. Chang., 16, 48-57, 2006.

Wang, X., Chen, F., Hasi, E., and Li, J.: Desertification in China, An assessment, Earth-Sci. Rev., 88, 188-206, 2008.

Wang, X., Yang, Y., Dong, Z., and Zhang, C.: Responses of dune activity and desertification in China to global warming in the twenty-first century, Global Planet. Change, 67, 167-185, 2009.

Wang, X., Zhang, C., Hasi, E., and Dong, Z.: Has the Three Norths Forest Shelterbelt Program solved the desertification and dust storm problems in arid and semiarid China?, J. Arid Environ., 74, 13-22, 2010.

Xie, L. W., Zhong, J., Chen, F. F., Cao, F. X., Li, J. J., and Wu, L. C.: Evaluation of soil fertility in the succession of karst rocky desertification using principal component analysis, Solid Earth, 6, 515-524, doi:10.5194/se-6-515-2015, 2015.

$\mathrm{Xu}$, E. Q. and Zhang, H. Q.: Characterization and interaction of driving factors in karst rocky desertification: a case study from Changshun, China, Solid Earth, 5, 1329-1340, doi:10.5194/se5-1329-2014, 2014.

Xue, X., Guo, J., Han, B., Sun, Q., and Liu, L.: The effect of climate warming and permafrost thaw on desertification in the QinghaiTibetan Plateau, Geomorphology, 108, 182-190, 2009.

Zhang, K., Qu, J., Han, Q., Xie, S., Kai, K., Niu, Q., and An, Z.: Wind tunnel simulation of windblown sand along China's Qinghai-Tibet railway, Land Degrad. Dev., 25, 244-250, 2014.

Zhu, Z.: Development trend of sandy desertification in interland agro-pastoral region of northern China in recent ten years, J. Desert Res., 14, 1-7, 1994. 